Abstracta Iranica Abstracta Iranica

Revue bibliographique pour le domaine irano-aryen

Volume 29 | 2008

Comptes rendus des publications de 2006

\title{
Afzâd. Ethnologie d'un village d'Iran. Téhéran, IFRI / Éd. Mo'in, 2006, 446 p., ill., bibl. (« Bibliothèque iranienne », 63)
}

\section{Rédaction}

\section{(2) OpenEdition}

Journals

Édition électronique

URL : http://journals.openedition.org/abstractairanica/33502

DOI : 10.4000/abstractairanica.33502

ISSN : 1961-960X

Éditeur :

CNRS (UMR 7528 Mondes iraniens et indiens), Éditions de l'IFRI

Édition imprimée

Date de publication : 15 mai 2008

ISSN : 0240-8910

Référence électronique

Rédaction, «Afzâd. Ethnologie d'un village d'Iran. Téhéran, IFRI / Éd. Mo'in, 2006, 446 p., ill., bibl. (" Bibliothèque iranienne »,63) », Abstracta Iranica [En ligne], Volume 29 | 2008, document 425, mis en ligne le 15 septembre 2008, consulté le 26 septembre 2020. URL : http://journals.openedition.org/ abstractairanica/33502 ; DOI : https://doi.org/10.4000/abstractairanica.33502

Ce document a été généré automatiquement le 26 septembre 2020.

Tous droits réservés 


\section{Afzâd. Ethnologie d'un village d'Iran. Téhéran, IFRI / Éd. Mo'in, 2006, 446 p., ill., bibl. (« Bibliothèque iranienne $», 63)$}

Rédaction

Publication remaniée de la thèse de doctorat de l'EHESS soutenue en 2004 et intitulée Comment peut-on être Afzâdi ? Individu et société dans un village persan (voir Abs. Ir. 27, c.r. $\left.\mathrm{n}^{\circ 0} 385\right)$.

INDEX

Thèmes : 16.1. Iran

\section{AUTEURS}

RÉDACTION

Directeur de la revue et secrétariats (Paris et Téhéran) 